The management of the learning curve was based in our experience in VATS, including 2-port technique anatomic pulmonary resections and the uniportal technique for wedge resections. Initially, we started performing lower lobectomies that were deemed less complex (Video 1), but these were rapidly followed by upper lobe resections (Video 2; Figure 2, $B$ ).

The 17 patients of our analysis (10 men and 7 women; mean age, 67.6 years; range, 43-81) underwent left lower lobectomy in $9(52.9 \%)$, right upper lobectomy in 2 , and right lower lobectomy and left upper lobectomy in 3 each. The mean surgical time was 134 minutes (range, 80-180). We aimed to perform a fissureless technique as the last step of the procedure, especially in upper resections.

Complete mediastinal lymphadenectomy was performed according to the oncologic criteria (Video 2). The mean number of nodal stations explored was 4.5 (range, 3-6), with a mean of $11.6 \pm 4.7$ lymph node resections (range, $5-18$ ). The mean tumor size was $2.8 \pm 1.1 \mathrm{~cm}$ (range, 1.2 4.8). The most common histologic type was squamous cell carcinoma (6 cases).

No postoperative mortality or readmission to the intensive care unit occurred. One patient developed a prolonged air leak (7 days) and another had atrial fibrillation. The mean duration of chest drainage was $2.4 \pm 1.3$ days (range, $1-7$ ), and the mean length of hospital stay was $2.8 \pm 1.2$ days (range, 2-7).

\section{DISCUSSION}

Most of the investigators have described the VATS approach to lobectomy using 3 to 4 incisions. However, the surgery can be performed using 2 ports ${ }^{1}$ or even by a single incision, as we have recently reported. ${ }^{2,3}$
Since June 2010 and after performing 95 cases using the 2-port approach, we have begun to perform uniportal VATS lobectomy, initially for lower lobes. ${ }^{4}$

Since 2004, Rocco and colleagues ${ }^{5}$ have published different studies leading the development of uniportal VATS techniques; however, anatomic lung resections were not performed. It is necessary, as described by Rocco and colleagues, ${ }^{5}$ to bring the instruments to address the target lesion from a vertical perspective rather than the traditional horizontal one.

One of the potential advantages is that only one intercostal space is involved, representing the most minimally invasive approach possible. We expect additional development of robotic technologies, which will probably allow the single-incision approach to become our standard surgical procedure for lobectomy.

In conclusion, we believe that single-incision VATS lobectomy is a feasible and promising procedure, especially when performed in centers with previous experience in the double-port VATS approach.

\section{References}

1. Villamizar N, Darrabie M, Burfeind W, Petersen R, Onaitis M, Toloza E, Harpole D, D'Amico T. Thoracoscopic lobectomy is associated with lower morbidity compared with thoracotomy. J Thorac Cardiovasc Surg. 2009;138: 419-25.

2. Gonzalez D, Delgado M, Paradela M, Fernandez R. Uni-incisional video-assisted thoracoscopic left lower lobectomy in a patient with an incomplete fissure. Innovat Technol Techniq Cardiothorac Vasc Surg. 2011;6:45-7.

3. Gonzalez D, Paradela M, Garcia J, de la Torre M. Single-port video-assisted thoracoscopic lobectomy. Interact Cardiovasc Thorac Surg. 2011;12:514-5.

4. Gonzalez D, de la Torre M, Paradela M, Fernandez R, Delgado M, Garcia J, Fieira E, Mendez L. Video-assisted thoracic surgery lobectomy: 3-year initial experience with 200 cases. Eur J Cardiothorac Surg. 2011;40:e21-8.

5. Rocco G, Martin-Ucar A, Passera E. Uniportal VATS wedge pulmonary resections. Ann Thorac Surg. 2004;77:726-8.

\title{
Takedown of cavopulmonary (Glenn) shunt: A technique using a right atrial flap
}

\author{
Christopher W. Baird, MD, and Joseph M. Forbess, MD, Dallas, Tex
}

\footnotetext{
From the University of Texas Southwestern Children's Medical Center at Dallas, Dallas, Tex.

Disclosures: Authors have nothing to disclose with regard to commercial support.

Received for publication Feb 16, 2011; revisions received July 8, 2011; accepted for publication Aug 4, 2011; available ahead of print Sept 12, 2011.

Address for reprints: Christopher W. Baird, MD, Children's Hospital Boston, Harvard

Medical School, 300 Longwood Ave, FA612, Boston, MA 02215 (E-mail:

Christopher.Baird@cardio.chboston.org).

J Thorac Cardiovasc Surg 2012;143:747-9

$0022-5223 / \$ 36.00$

Copyright (c) 2012 by The American Association for Thoracic Surgery

doi:10.1016/j.jtcvs.2011.08.011
}

Traditionally, the bidirectional Glenn shunt has been used as a palliative operation in patients with functional single ventricles. More recently, it has also been used to augment pulmonary blood flow in patients with Ebstein's anomaly and marginal right ventricular function, ${ }^{1}$ and patients with hypoplastic left heart syndrome as an adjunct in operations attempting biventricular repairs. Patients who successfully achieve ventricular rehabilitation resulting in a functional biventricular heart no longer require the cavopulmonary anastomosis. Historically, several authors have reported 


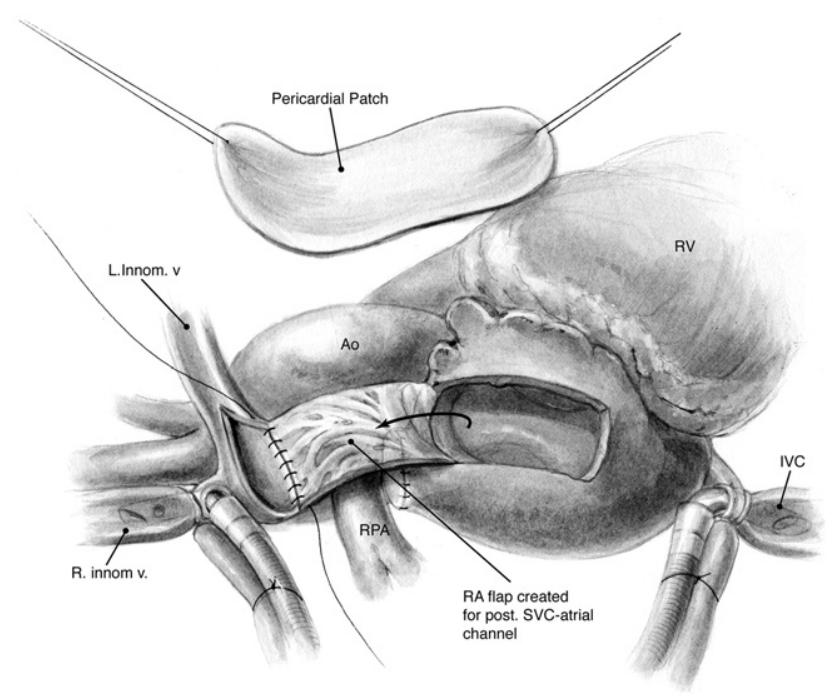

FIGURE 1. Cavopulmonary anastomosis is created by using a flap of right atrial free wall to form the posterior and lateral walls of the neo-superior vena cava $(S V C)$ and a generous pericardial patch (or pulmonary homograft) is used to reconstruct the anterior neo-SVC. $R V$, Right ventricle; $R P A$, right pulmonary artery; $A o$, aorta; $I V C$, inferior vena cava.

techniques for bidirectional Glenn takedown, but most are direct reanastomosis between the superior vena cava (SVC) and the right atrium (RA). ${ }^{2-4}$ We report a new technique that is similar but slightly modified from Danielson's atriopulmonary connection with lateral tunnel modification, ${ }^{5}$ whereby a flap of right atrial tissue is used to reestablish tension-free SVC-RA continuity while preserving sinus node function.

\section{CLINICAL SUMMARY}

We have performed this reconstruction in at least 4 patients undergoing concomitant procedures resulting in biventricular repairs. One patient had a short residual segment of SVC that ended at the retroaortic innominate vein junction, which required an extended flap of right atrial tissue. In each case, cardiopulmonary bypass was established with ascending aortic, innominate vein, and inferior vena cava cannulation. Concomitant procedures were generally performed first, and the SVC-RA connection was completed after removal of the aortic crossclamp during rewarming. Particular attention was paid if a right atriotomy was required for intracardiac access for concomitant procedures because a portion of intact atrium is required for the atrial flap reconstruction. The cavopulmonary anastomosis was taken down, and the resultant right pulmonary artery defect was reconstructed with pulmonary homograft, autologous pericardium, or bovine pericardium. For SVC-RA reconstruction, a U-shaped incision was made beginning at the right atrial appendage

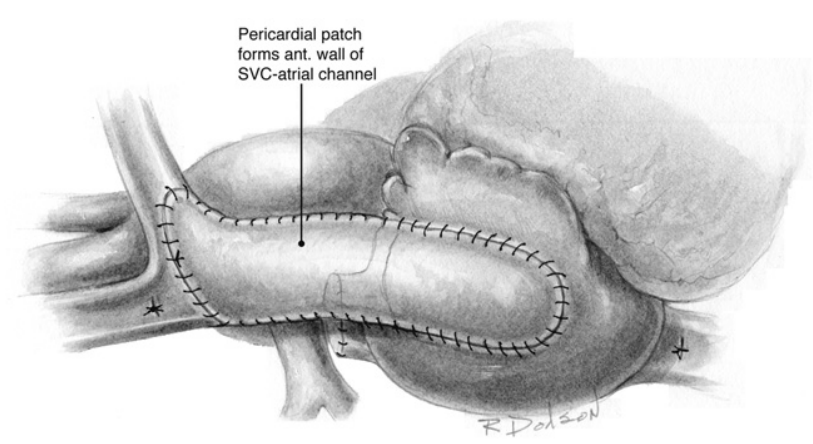

FIGURE 2. Completed right atrial superior vena cava $(S V C)$ reconstruction.

continuing inferiorly and back toward the RA-SVC junction (Figure 1). This flap of RA tissue was laid superiorly to form the posterior and lateral walls of the neo-SVC. The superior portion of the atrial flap was sutured to the native distal SVC with continuous interlocking 6.0 polypropylene sutures. A generous piece of pulmonary homograft was fashioned in a funnel shape to reconstruct the anterior SVC and lateral right atrial wall recreating the SVC-RA junction (Figure 2). After weaning from cardiopulmonary bypass, echocardiogram or direct SVC pressure measurements were used to access adequacy of the reconstruction. Aspirin was generally used for anticoagulation. At discharge and latest follow-up (range, 1-6 years), all patients were in sinus rhythm and without SVC obstruction.

\section{DISCUSSION}

There are several advantages of this technique over primary reanastomosis of the SVC and RA. When creating a large tension-free cavopulmonary artery anastomosis, one often uses a long segment of SVC directly dividing the SVC at the cavoatrial junction. Over time, the cavopulmonary anastomosis retracts superiorly, limiting the amount of SVC length for cavoatrial reconstruction. There have been reports of using polytetrafluoroethylene grafts in adult patients $^{6}$; however, these grafts required the use of Coumadin anticoagulation and lack the ability to grow.

\section{CONCLUSIONS}

Using autologous RA tissue limits the use of foreign conduits and anticoagulation, and provides the growth potential necessary in many pediatric patients. When reestablishing a direct SVC-RA connection, dissection is generally required near the sinoatrial node and artery. However, this is not necessary when using a flap of right atrial tissue because the atrial flap folds back over the sinoatrial nodal area, minimizing any chance of injury. This technique allows a generous SVC-RA connection that is easily 
customized for each individual patient and that is quickly and easily reproducible.

\section{References}

1. Malhotra SP, Petrossian E, Reddy VM, Qiu M, Meada K, Suleman S, et al. Selective right ventricular unloading and novel technical concepts in Ebstein's anomaly. Ann Thorac Surg. 2009;88:1975-81

2. Pacifico AD, Kirklin JW. Takedown of cava-pulmonary artery anastomosis (Glenn) during repair of congenital cardiac malformations: report of 5 cases. J Thorac Cardiovasc Surg. 1975;70:272-7.
3. Marcelletti C, Wallace RB, Ritter DG. Reconstruction of superior vena cava-right atrial continuity and "anatomic" repair of transposition of great arteries with ventricular septal defect. Mayo Clin Proc. 1976;51:163-6.

4. Rohmer J, Quaegebeur JM, Brom A. Takedown and reconstruction of cavopulmonary anastomosis. Ann Thorac Surg. 1977;23:129-34.

5. Durongpisitkul K, Porter CJ, Cetta F, Offord KP, Slezak JM, Puga FJ, et al. Predictors of early- and late-onset supraventricular tachyarrhythmias after Fontan operation. Circulation. 1998;98:1099-107.

6. Bruckheimer E, Bulbul ZR, Hellendrand WE, Kleinman CS, Kopf GS. Takedown of Glenn shunts in adults with congenital heart disease with polytetrafluoroethylene grafts: technique and long-term follow-up. J Thorac Cardiovasc Surg. 1997;113:607-8.

\title{
Simplified nonresectional leaflet remodeling mitral valve repair for degenerative mitral regurgitation
}

\author{
Y. Joseph Woo, MD, and John W. MacArthur, Jr, MD, Philadelphia, Pa
}

Video clip is available online.

Mitral valve repair surgery for mitral regurgitation (MR) has a multi-decade history beginning in the 1950s with Davila and colleagues' ${ }^{1}$ circumferential suture mitral annuloplasty and Lillehei and colleagues, ${ }^{2}$ suture commissural fusion. In 1960, McGoon ${ }^{3}$ pioneered direct leaflet repair via interrupted suture plication of the prolapsed leaflet segment. By the next decade, Carpentier and colleagues ${ }^{4}$ had developed a host of novel reconstructive techniques ranging from leaflet resection to native chordal repositioning, all augmented by remodeling prosthetic ring annuloplasty. Decades later, the classic quadrangular resection remains for most surgeons, the mitral valve repair technique of choice. The capability for high-probability mitral repair success now justifies early operation in asymptomatic patients. ${ }^{5}$ The opportunity for patients to undergo minimally invasive operations and percutaneous transcatheter repair has only

\footnotetext{
From the Division of Cardiovascular Surgery, University of Pennsylvania, Philadelphia, Pa.

Disclosures: Authors have nothing to disclose with regard to commercial support.

Read at the 37th Annual Meeting of The Western Thoracic Surgical Association, Colorado Springs, Colorado, June 22-25, 2011.

Received for publication June 21, 2011; revisions received Aug 4, 2011; accepted for publication Aug 24, 2011; available ahead of print Sept 26, 2011.

Address for reprints: Y. Joseph Woo, MD, Associate Professor of Surgery, Division of Cardiovascular Surgery, Department of Surgery, University of Pennsylvania School of Medicine, Silverstein Building, 6th Floor, 3400 Spruce St, Philadelphia, PA 19104 (E-mail: jwoo@uphs.upenn.edu)

J Thorac Cardiovasc Surg 2012;143:749-53

$0022-5223 / \$ 36.00$

Copyright (c) 2012 by The American Association for Thoracic Surgery

doi:10.1016/j.jtcvs.2011.08.024
}

further magnified the drive toward earlier surgery and the need for near $100 \%$ valve repair success. ${ }^{6-9}$

Despite the overwhelming success of quadrangular resection, minor drawbacks persist relating to irreversibility of leaflet resection, time-consuming leaflet reapproximation with sliding annuloplasty, monoleaflet function, and systolic anterior motion (SAM) risk. Neochord construction mitigates many of these but has the challenge of precise sizing and possibility of leaving excessive tissue, risking SAM. In seeking a mitral repair technique that avoids the potential negatives of leaflet resection and neochords, while also facilitating minimally invasive operations by reducing leaflet manipulation and simplifying suture management, we used a slight modification of the $\mathrm{McGoon}^{3}$ plication repair in 87 patients. Single suture imbrication of excess prolapsed tissue onto the noncoaptation ventricular side of the leaflet efficiently remodeled the leaflet into a smooth nonprolapsed coapting surface.

\section{OPERATIVE TECHNIQUE}

A minimally invasive approach was used in the majority of patients and has been described by Woo. ${ }^{6}$ In these patients and patients undergoing sternotomy, mitral ring annuloplasty sutures were placed immediately after atriotomy and retracted under slight tension to optimize exposure and inspection of leaflet pathology (Figure 1, A). As originally $^{3}$ and subsequently ${ }^{10}$ described, the McGoon repair entailed an interrupted suture placed through the leaflet margin at one end of the prolapsed segment and brought out through the other end. Additional sutures were placed in parallel toward the annulus with progressively widening amount of leaflet tissue sutured. Tying the sutures pleated the leaflet, generating "slight bulkiness of the plicated portion" $" 10$ and eliminating the prolapse. 